\title{
PENGARUH PEMBERIAN ANGKAK (RED YEAST RICE) TERHADAP KADAR GLUKOSA DARAH PUASA PADA WANITA PREDIABETES
}

\author{
Afina Rachma Sulistyaning, Yekti Wirawanni ${ }^{*}$ \\ Program Studi Ilmu Gizi Fakultas Kedokteran Universitas Diponegoro \\ Jl.Dr.Sutomo No.18, Semarang, Telp (024) 8453708, Email : gizifk@ undip.ac.id
}

\begin{abstract}
Background: Diabetic is effectively treated in early stage before symptoms occurs called pre-diabetic. Pre-diabetic is marked with elevating fasting blood glucose $(G B F)$ in 100-125 mg/dl. Red yeast rice is fermented by mold Monascus purpureous which has been associated with improvement of glucose tolerance and decrease blood glucose. This research intends to prove consumption of Red yeast rice on FBG in pre-diabetic women.

Method: This research was true experiment study with pre test-post test design. The subjects were employees in BPPT, Bappeda, BPS and Pangudi luhur institution in Semarang. Sample included 28 women was taken by purposive sampling and then split into 2 groups by simple randomization. Group 1 was treated with 5.4 grams Red yeast rice for 14 days and group 2 was treated with filtration of roasted-rice. The measurement of FBG was taken before and after intervention using spectrophotometer methods. Food intake of the subject were taken twice, before intervention using food recall methods $3 \times 24$ hours and during the intervention using food recall methods $5 \times 24$ hours. Data were analyzed statistically using Independent t-test, Mann-Whitney test, Paired t-test, Correlation and Linier Regression.

Result: FBG level in group 1 was significantly decreased $(p=0.006)$ by $9.14 \pm 10.48 \mathrm{mg} / \mathrm{dl}$ and FBG level in group 2 increased by $1.35 \pm 7.39 \mathrm{mg} / \mathrm{dl}$. There was significant FBG level different change between group 1 and group 2 statistically $(p=0.005)$

Conclusion: There is significant fasting blood glucose decrease after 14 days treatment with 5.4 grams Red yeast rice.

Key word: Red yeast Rice; fasting blood glucose; pre-diabetic women.
\end{abstract}

\section{ABSTRAK}

Latar Belakang : Manajemen DM efektif dilakukan pada tahap awal sebelum timbul gejala atau prediabetes. Prediabetes ditandai dengan kadar glukosa darah puasa (GDP) mencapai 100 - 125 mg/dl. Angkak merupakan beras hasil fermentasi oleh kapang Monascus purpureous yang dikaitkan dengan perbaikan toleransi glukosa dan penurunan kadar glukosa darah. Penelitian ini bertujuan untuk membuktikan pengaruh pemberian angkak terhadap kadar GDP pada wanita prediabetes.

Metode : Jenis penelitian adalah true experiment dengan pre test-post test design. Subjek penelitian adalah karyawati kantor BPPT, Bappeda, BPS, dan yayasan Pangudi Luhur Kota Semarang yang diambil secara purposive sampling sebanyak 28 orang dan dibagi menjadi 2 kelompok secara simple randomization. Kelompok perlakuan diberi angkak 5,4 gram selama 14 hari, sedangkan kelompok kontrol diberi air filtrasi beras sangrai. Pengukuran kadar GDP dilakukan sebelum dan setelah intervensi dengan metode spektrofotometri. Asupan makan subjek sebelum intervensi diperoleh dengan metode food recall $3 \times 24$ jam dan selama intervensi dengan metode food recall $5 \times 24$ jam. Analisis statistik menggunakan Independent sample t-test, Mann-Whitney test, Paired t-test, korelasi dan regresi linear.

Hasil : Kelompok perlakuan mengalami penurunan kadar GDP yang bermakna ( $p=0.006)$ sebesar 9.14 \pm 10.48 $\mathrm{mg} / \mathrm{dl}$ sedangkan kelompok kontrol mengalami peningkatan sebesar $1.35 \pm 7.39 \mathrm{mg} / \mathrm{dl}$. Secara statistik, terdapat perbedaan perubahan kadar GDP antara kelompok perlakuan dan kontrol yang bermakna $(p=0.005)$.

Simpulan : Terdapat penurunan kadar GDP yang bermakna setelah pemberian 5,4 mg angkak selama 14 hari.

Kata kunci : Angkak; kadar glukosa darah puasa; wanita prediabetes

\section{PENDAHULUAN}

Diabetes mellitus (DM) merupakan sekumpulan gangguan metabolik yang ditandai dengan peningkatan konsentrasi glukosa darah dan gangguan metabolisme insulin. Penderita DM tidak dapat mensekresi insulin dalam jumlah cukup atau menggunakan insulin secara efektif, maupun keduanya. ${ }^{1}$ Efek jangka panjang pada DM dapat mengakibatkan gangguan makrovaskular dan mikrovaskular. $^{2}$

Berdasarkan data WHO tahun 2009, DM menjadi salah satu faktor risiko terbesar kematian akibat penyakit kardiovaskular di dunia. ${ }^{3}$ Tahun 2010, penderita gangguan toleransi glukosa dan DM pada orang dewasa usia 20-79 tahun di seluruh dunia mencapai 285 juta jiwa dan diperkirakan 
pada tahun 2030 meningkat hingga 439 juta jiwa. ${ }^{4}$ Menurut WHO, pada tahun 2000 Indonesia menempati peringkat ke 4 penderita diabetes terbanyak di seluruh dunia dengan jumlah 8,4 juta jiwa dan diperkirakan mencapai 21,3 juta jiwa pada 2030. ${ }^{5}$ Berdasarkan data World Health Statistics 2012, angka kematian karena penyakit kardiovaskular dan diabetes di Indonesia dalam rentang usia 30-70 tahun pada 100.000 populasi sebanyak 308 kasus. $^{6}$ Di Kota Semarang pada tahun 2010, DM berada di tempat kedua sebagai penyakit tidak menular terbanyak dengan prevalensi $20,5 \%{ }^{7}$

Peningkatan angka kejadian DM menunjukkan bahwa pencegahan dan penatalaksaan secara dini penting untuk dilakukan guna mengatasi penyakit tersebut. Manajemen DM efektif diimplementasikan pada tahap prediabetes atau belum timbul gejala DM. ${ }^{8}$ Prediabetes ditandai dengan kadar glukosa darah puasa (GDP) mencapai $100-125 \mathrm{mg} / \mathrm{dl} .{ }^{9}$ Penderita prediabetes di Indonesia lebih banyak terjadi pada wanita dengan prevalensi $61.6 \%{ }^{10}$

Pengendalian kadar GDP pada penderita prediabetes dapat dilakukan dengan beberapa cara, antara lain: pengaturan diet, peningkatan aktivitas fisik, dan peningkatan pengetahuan terkait diabetes. ${ }^{2}$ Dalam pengaturan diet, salah satu bahan makanan yang berpotensi menurunkan kadar glukosa darah adalah angkak. Angkak merupakan beras hasil fermentasi kapang Monascus purpureous yang memiliki manfaat terhadap penurunan kadar glukosa darah pada tikus diabetes. ${ }^{11,12}$

Berdasarkan penelitian yang dilakukan pada tikus galur Wistar yang diinduksi dengan streptozotocin, pemberian 2.4 gram angkak selama 30 hari dapat menurunkan kadar glukosa darah tikus diabetes dari $512 \mathrm{mg} / \mathrm{dl}$ menjadi $132 \mathrm{mg} / \mathrm{dl} .{ }^{11}$ Penelitian lain yang juga dilakukan pada tikus galur wistar menunjukkan pemberian $150 \mathrm{mg}$ angkak sebanyak 3 kali sehari selama 3 hari pada tikus yang telah diberi diet tinggi fruktosa selama 4 minggu dapat menurunkan glukosa darah dari $146,2 \mathrm{mg} / \mathrm{dl}$ menjadi $118,4 \mathrm{mg} / \mathrm{dl} .^{12}$

Mekanisme penurunan kadar glukosa darah pada tikus dimungkinkan terjadi karena pigmen merah angkak mengandung zat antosianin dari kelompok flavonoid yang mempunyai antioksidan kuat. ${ }^{13}$ Oleh karena itu, pemberian angkak efektif digunakan sebagai terapi penurunan kadar glukosa darah karena memiliki efek hipoglikemik
Penelitian ini bertujuan untuk melihat pengaruh pemberian angkak terhadap kadar glukosa darah puasa pada wanita prediabetes.

\section{METODE PENELITIAN}

Penelitian ini dilakukan di kantor Badan Pusat Statistik (BPS) Provinsi Jawa Tengah, Badan Pusat Perijinan Terpadu (BPPT) Kota Semarang, Badan Perencanaan Pembangunan (Bappeda) Kota Semarang dan yayasan Pangudi Luhur Semarang pada bulan Juni - Juli 2013. Jenis penelitian adalah true experiment dengan pre-post test design. Subjek penelitian adalah karyawati kantor BPS, BPPT, Bappeda dan yayasan Pangudi Luhur yang diambil secara purposive sampling. Besar subjek dalam penelitian adalah 28 orang. Kriteria inklusi subjek antara lain wanita usia produktif (belum mengalami menopause), IMT $23 \mathrm{~kg} / \mathrm{m}^{2}-30 \mathrm{~kg} / \mathrm{m}^{2}$, kadar glukosa darah puasa $100-125 \mathrm{mg} / \mathrm{dl}$, tidak mengonsumsi obat-obatan yang dapat mengendalikan kadar glukosa darah selama penelitian, tidak dalam keadaan sakit atau perawatan dokter dan bersedia mengisi informed consent penelitian. Kriteria eksklusi adalah meninggal saat penelitian berlangsung dan mengundurkan diri saat penelitian berlangsung.

Prosedur pertama dalam penelitian ini adalah memberikan penjelasan tentang maksud penelitian, metode, risiko dan ketidaknyamanan yang akan dialami serta keuntungan yang diperoleh subjek penelitian. Setelah itu peneliti menawarkan kesediaan menjadi subjek penelitian. Subjek yang telah bersedia diminta untuk menandatangani informed consent. Selanjutnya, dilakukan pengukuran berat badan (BB) dan tinggi badan (TB) untuk mengetahui IMT, wawancara data umum subjek serta skrining kadar glukosa darah puasa.

Sebanyak 32 subjek yang memenuhi kriteria inklusi dibagi menjadi 2 kelompok menggunakan simple randomization. Kelompok perlakuan diberikan angkak sebanyak 5,4 gram selama 14 hari, sedangkan kelompok kontrol diberikan filtrat beras sangrai dengan penambahan sirup rendah kalori $25 \mathrm{ml}$ berwarna merah agar menyerupai angkak yang diberikan pada kelompok perlakuan. Dosis pemberian angkak berdasarkan dosis yang diberikan pada tikus dalam penelitian sebelumnya yang dapat menurunkan kadar glukosa darah tikus secara bermakna ${ }^{12}$. Setelah pemberian angkak selama 14 hari, hari ke-15 dilakukan pengambilan darah pada kelompok perlakuan dan kontrol untuk mengetahui kadar glukosa darah puasa. Kepatuhan dan waktu mengkonsumsi 
angkak kelompok perlakuan dan air seduhan beras sangrai kelompok kontrol dipantau dengan menggunakan formulir chek list yang diisi oleh peneliti dengan menanyakan langsung kepada subjek penelitian.

Data yang dikumpulkan melalui wawancara adalah data umum subjek, data asupan makan dan aktifitas fisik. Data yang dikumpulkan melalui pengukuran antropometri adalah data berat badan yang diperoleh melalui penimbangan dengan timbangan digital dan data tinggi badan yang diperoleh melalui pengukuran dengan microtoise. Pengukuran laboratorium yaitu kadar glukosa darah puasa dilakukan oleh petugas laboratorium "Permata" menggunakan metode spektrofotometri.

Variabel bebas pada penelitian ini adalah pemberian angkak yang merupakan produk fermentasi beras oleh kapang Monascus purpureous yang diperoleh dari produsen angkak dalam bentuk kemasan. Angkak sebanyak 5,4 gram direbus dengan air sebanyak $200 \mathrm{ml}$ sampai mendidih kemudian disaring lalu dilakukan penambahan sirup rendah kalori $25 \mathrm{ml}$ untuk mengurangi rasa pahit. Angkak diberikan sekali dalam sehari di luar jam makan utama selama 14 hari. Variabel terikat adalah kadar glukosa darah puasa dengan satuan $\mathrm{mg} / \mathrm{dl}$ yang diambil oleh petugas laboratorium "Permata" melalui pembuluh vena di lengan setelah subyek berpuasa selama 10 jam dengan metode spektrofotometri. Variabel perancu adalah asupan energi, karbohidrat, lemak, protein dan serat selama penelitian yang diperoleh dengan metode food recall 5x24 jam dan diolah menggunakan nutrisurvey.

Data yang diperoleh dianalisis secara statistik. Gambaran karakteristik subjek dianalisis dengan analisis deskriptif. Uji normalitas data glukosa darah puasa sebelum dan setelah perlakuan menggunakan uji Shapiro Wilk. Data berdistribusi normal sehingga untuk menguji perbedaan kadar glukosa darah puasa sebelum dan setelah perlakuan pada kedua kelompok digunakan Uji Paired t-test, sedangkan untuk mengetahui perbedaan penurunan kadar glukosa darah puasa pada kelompok kontrol dan perlakuan dilakukan uji Independent sample ttest.

\section{HASIL PENELITIAN}

Skrining dilakukan pada 102 orang wanita yang bersedia diperiksa kadar glukosa darah puasa dan sebanyak 32 orang dari jumlah tersebut memenuhi kriteria inklusi menjadi subjek penelitian. Akan tetapi sebanyak 1 orang subjek dari kelompok perlakuan dan 2 orang subjek dari kelompok kontrol tidak bersedia diambil darah saat post test, dan 1 orang subjek pada kelompok perlakuan tidak kuat mengonsumsi angkak karena menderita gastritis sehingga jumlah subjek yang mengikuti penelitian hingga akhir sebanyak 28 orang dan memenuhi besar sampel minimal yaitu 14 orang untuk tiap kelompok perlakuan. Karakteristik dan keadaan subjek pada awal penelitian disajikan pada tabel 1 untuk melihat homogenitas variabel antara kelompok kontrol dan perlakuan.

Tabel 1. Karakteristik dan Keadaan Subjek pada Awal Penelitian

\begin{tabular}{|c|c|c|c|c|c|c|c|}
\hline \multirow[t]{2}{*}{ Variabel } & \multirow{2}{*}{$\begin{array}{c}\begin{array}{c}\text { Perlakuan } \\
(\mathrm{n}=14)\end{array} \\
\text { Mean } \pm \text { SD }\end{array}$} & \multirow{2}{*}{$\begin{array}{c}\begin{array}{c}\text { Kontrol } \\
(\mathrm{n}=14)\end{array} \\
\text { Mean } \pm \text { SD }\end{array}$} & \multirow[t]{2}{*}{$\mathrm{p}$} & \multicolumn{2}{|c|}{$\begin{array}{c}\text { Perlakua } \\
n \\
(n=14) \\
\end{array}$} & \multicolumn{2}{|c|}{$\begin{array}{c}\text { Kontrol } \\
(n=14)\end{array}$} \\
\hline & & & & f & $\%$ & $\mathrm{f}$ & $\%$ \\
\hline Usia & $42.21 \pm 9.21$ & $43.21 \pm 3.15$ & $0.744^{\mathrm{a}}$ & & & & \\
\hline Kelompok Usia & & & & 5 & 35.7 & 3 & 21.4 \\
\hline $30-39$ tahun & & & & 6 & 42.9 & 9 & 64.3 \\
\hline $40-49$ tahun & & & & 3 & 21.4 & 2 & 14.3 \\
\hline $50-59$ tahun & & & & & & & \\
\hline IMT & $27.78 \pm 3.23$ & $26.30 \pm 9.68$ & $0.233^{\mathrm{a}}$ & & & & \\
\hline Kategori IMT & & & & & & & \\
\hline Overweight $\left(23-24,9 \mathrm{~kg} / \mathrm{m}^{2}\right)$ & & & & 2 & 7.1 & 7 & 25 \\
\hline Obesitas I $\left(25-29,9 \mathrm{~kg} / \mathrm{m}^{2}\right)$ & & & & 9 & 32.1 & 5 & 17.9 \\
\hline Obesitas II $\left(\geq 30 \mathrm{~kg} / \mathrm{m}^{2}\right)$ & & & & 3 & 10.7 & 2 & 7.1 \\
\hline Kadar GDP & $111.50 \pm 8.51$ & $110.07 \pm 5.14$ & $0.596^{\mathrm{a}}$ & & & & \\
\hline
\end{tabular}


Sebagian besar subjek berada pada kelompok usia 40 - 49 tahun dan lebih banyak ditemukan pada kelompok kontrol dibandingkan dengan kelompok perlakuan. Indeks massa tubuh (IMT) sebagian besar subjek tergolong obesitas tingkat 1, yang lebih banyak ditemukan pada kelompok perlakuan. Berdasarkan uji independent t-test, tidak terdapat perbedaan usia, IMT dan kadar GDP yang bermakna antara kelompok perlakuan dan kelompok kontrol. Hal ini menggambarkan bahwa keadaan awal subjek penelitian adalah homogen.

Daya Terima Angkak pada Kelompok Perlakuan
Rerata asupan angkak pada kelompok perlakuan adalah 98.98\%. Hal ini disebabkan karena 1 orang subjek beberapa kali menyisakan \pm $25 \%$ angkak karena tidak kuat dengan rasa pahit dan 1 orang subjek pada hari ke-11 lupa mengonsumsi angkak.

\section{Keadaan Kadar Glukosa Darah Puasa Setelah Intervensi}

Keadaan kadar GDP setelah intervensi disajikan untuk melihat apakah ada perbedaan kadar GDP antara kelompok perlakuan setelah diberi angkak 5.4 gram selama 14 hari dengan kelompok kontrol yang diberi beras sangrai selama 14 hari.

Tabel 3. Keadaan Kadar Glukosa Darah Puasa Setelah Intervensi

\begin{tabular}{cccc}
\hline \multirow{2}{*}{ Variabel } & perlakuan $(\mathrm{n}=14)$ & $\begin{array}{c}\text { Kontrol } \\
(\mathrm{n}=14)\end{array}$ & $\mathrm{p}$ \\
\cline { 2 - 3 } & Mean $\pm \mathrm{SD}$ & Mean \pm SD & \\
\hline Kadar GDP & $102.36 \pm 11.26$ & $111.43 \pm 9.68$ & $0.031^{\mathrm{a}^{*}}$ \\
\hline
\end{tabular}

Keterangan: $p^{*}=$ beda bermakna, $a=$ independent $t$-test

Hasil uji independent t-test pada tabel 3 menunjukkan rerata kadar GDP kelompok perlakuan setelah intervensi lebih rendah (102.36 \pm 11.26) dibandingkan kelompok kontrol (111.43 \pm 9.68) dan terdapat perbedaan yang bermakna antara kelompok perlakuan dan kelompok kontrol setelah intervensi $(p<0.05)$.

\section{Perbedaan Kadar Glukosa Darah Puasa Sebelum dan Setelah Intervensi}

Tabel perbedaan kadar GDP sebelum dan setelah intervensi disajikan untuk melihat perubahan rerata kadar GDP kelompok kontrol dan perlakuan sebelum dan setelah konsumsi angkak selama 14 hari.

Tabel 4. Perbedaan kadar GDP sebelum dan setelah intervensi

\begin{tabular}{|c|c|c|c|c|c|}
\hline \multirow[b]{2}{*}{ Variabel } & \multicolumn{2}{|c|}{ GDP } & \multirow[b]{2}{*}{$\mathrm{p}^{\mathrm{a}}$} & \multirow[b]{2}{*}{$\begin{array}{l}\Delta \mathrm{GDP} \\
(\mathrm{mg} / \mathrm{dl})\end{array}$} & \multirow[b]{2}{*}{$\mathrm{P}^{\mathrm{b}}$} \\
\hline & $\begin{array}{l}\text { sebelum } \\
\text { intervensi } \\
(\mathrm{mg} / \mathrm{dl})\end{array}$ & $\begin{array}{l}\text { setelah } \\
\text { intervensi } \\
(\mathrm{mg} / \mathrm{dl})\end{array}$ & & & \\
\hline \multicolumn{6}{|l|}{$\begin{array}{l}\text { Perlakuan } \\
(\mathrm{n}=14)\end{array}$} \\
\hline Mean \pm SD & $111.50 \pm 8.51$ & $102.36 \pm 11.26$ & $\begin{array}{l}0.006 \\
*\end{array}$ & $\begin{array}{l}-9.14 \\
10.48\end{array}$ & $\begin{array}{l} \pm \quad 0.005 \\
*\end{array}$ \\
\hline \multicolumn{6}{|l|}{ Kontrol $(n=14)$} \\
\hline Mean \pm SD & $110.07 \pm 5.14$ & $111.43 \pm 9.68$ & 0.504 & $1.35 \pm 7.39$ & \\
\hline
\end{tabular}

Kelompok perlakuan mengalami penurunan kadar GDP yang bermakna $(p=0.006)$ setelah pemberian angkak selama 14 hari yaitu sebesar $-9.14 \pm 10.48 \mathrm{mg} / \mathrm{dl}$. Berdasarkan uji independent t-test, terdapat perbedaan perubahan kadar GDP $(\Delta \mathrm{GDP})$ yang bermakna $(p=0,005)$ antara kelompok perlakuan $(-9.14 \pm 10.47 \mathrm{mg} / \mathrm{dl})$ dan kelompok kontrol $(1.35 \pm 7.39 \mathrm{mg} / \mathrm{dl})$.

\section{Asupan Makan Sebelum Intervensi}

Asupan makan dapat mempengaruhi kadar glukosa darah puasa. Data asupan meliputi energi, protein, lemak, karbohidrat dan serat. Perbedaan asupan makan antara kelompok kontrol dan perlakuan sebelum penelitian disajikan untuk melihat homogenitas asupan makanan sebelum penelitian. 
Tabel 5. Asupan Makan Sebelum Intervensi

\begin{tabular}{|c|c|c|c|c|c|}
\hline \multirow[t]{2}{*}{ Variabel } & $\begin{array}{l}\text { Perlakuan } \\
(\mathrm{n}=14)\end{array}$ & \multirow{2}{*}{$\begin{array}{c}\text { Tingkat } \\
\text { Kecukupa } \\
\text { n }\end{array}$} & Kontrol $(n=14)$ & \multirow{2}{*}{$\begin{array}{c}\text { Tingkat } \\
\text { Kecukupa } \\
\text { n }\end{array}$} & \multirow[t]{2}{*}{$\mathrm{p}$} \\
\hline & Mean \pm SD & & Mean \pm SD & & \\
\hline Asupan energi & $\begin{array}{c}1758.36 \pm \\
277.16\end{array}$ & $100.48 \%$ & $\begin{array}{c}1644.52 \pm \\
631.10\end{array}$ & $93.97 \%$ & $0.168^{\mathrm{b}}$ \\
\hline Asup & $65.29 \pm 14.09$ & $99.48 \%$ & $54.23 \pm 27.61$ & $82.63 \%$ & $0.027^{b^{*}}$ \\
\hline Asupan lemak & $56.19 \pm 23.32$ & $115.56 \%$ & $60.99 \pm 40.22$ & $125.47 \%$ & $0.703^{\mathrm{a}}$ \\
\hline $\begin{array}{l}\text { Asupan } \\
\text { karbohidrat }\end{array}$ & $248.17 \pm 51.63$ & $94.54 \%$ & $221.85 \pm 77.28$ & $84.51 \%$ & $0.299^{\mathrm{a}}$ \\
\hline Asupan serat & $9.76 \pm 3.79$ & $22.31 \%$ & $9.87 \pm 4.39$ & $22.56 \%$ & $0.927^{\mathrm{b}}$ \\
\hline
\end{tabular}

Keterangan: $p^{*}=$ beda bermakna, $a=$ Independent $t$-test, $b=$ Mann-Whitney

Tabel 5 menunjukkan tidak terdapat perbedaan yang bermakna pada asupan energi, lemak, karbohidrat dan serat antara kelompok kontrol dan perlakuan sebelum intervensi $(p>$ $0.05)$, namun terdapat perbedaan asupan protein sebelum intervensi yang bermakna antara kedua kelompok $(p<0.05)$.

\section{Asupan Makan Selama Intervensi}

Data asupan makan selama intervensi disajikan untuk melihat perbedaan asupan makan subjek selama intervensi pada kelompok kontrol dan perlakuan.

Tabel 6. Asupan Makan Selama Intervensi

\begin{tabular}{|c|c|c|c|c|c|}
\hline \multirow[t]{2}{*}{ Variabel } & $\begin{array}{c}\text { Perlakuan } \\
(n=14)\end{array}$ & \multirow{2}{*}{$\begin{array}{c}\text { Tingkat } \\
\text { Kecukupa } \\
\mathrm{n}\end{array}$} & Kontrol $(n=14)$ & \multirow{2}{*}{$\begin{array}{c}\text { Tingkat } \\
\text { Kecukupa } \\
\text { n }\end{array}$} & \multirow[t]{2}{*}{$p^{*}$} \\
\hline & Mean \pm SD & & Mean \pm SD & & \\
\hline Asupan energi & $\begin{array}{c}1597.77 \pm \\
354.74\end{array}$ & $91.30 \%$ & $\begin{array}{c}1726.01 \pm \\
375.04\end{array}$ & $98.63 \%$ & $0.361^{\mathrm{a}}$ \\
\hline Asup & $57.02 \pm 14.78$ & $86.88 \%$ & $65.58 \pm 13.27$ & $99.92 \%$ & 0.11 \\
\hline Asupan lemak & $51.94 \pm 15.64$ & $106.85 \%$ & $63.20 \pm 25.81$ & $130.01 \%$ & $0.177^{\mathrm{a}}$ \\
\hline Asupan & $226.46 \pm 49.18$ & $86.27 \%$ & $222.68 \pm 53.65$ & $84.83 \%$ & $0.848^{\mathrm{a}}$ \\
\hline Asupan serat & $9.82 \pm 4.90$ & $22.46 \%$ & $11.37 \pm 5.70$ & $25.99 \%$ & $0.383^{\mathrm{b}}$ \\
\hline
\end{tabular}

Keterangan: $a=$ Independent $t$-test, $b=$ Mann-Whitney

Tabel 6 menunjukkan tidak terdapat perbedaan asupan energi, protein, lemak, karbohidrat dan serat yang bermakna antara kelompok perlakuan dan kontrol selama intervensi $(p>0.05)$. Rerata asupan energi, protein, lemak, dan serat selama intervensi kelompok perlakuan lebih rendah dari kelompok kontrol.

\section{Perubahan Asupan Makan Sebelum dan Selama Intervensi}

Perubahan asupan makan subjek sebelum dan selama intervensi dapat menjadi salah satu faktor yang berperan dalam perubahan kadar gula darah subjek. Perubahan asupan makan tersebut dapat dilihat pada tabel di bawah ini:

Tabel 7. Perubahan Asupan Makan Sebelum dan Selama Intervensi

\begin{tabular}{lccc}
\hline \multicolumn{1}{c}{ Variabel } & Perlakuan $(\mathrm{n}=14)$ & Kontrol $(\mathrm{n}=14)$ & \multirow{2}{*}{$p^{*}$} \\
\cline { 2 - 3 } & Mean $\pm \mathrm{SD}$ & Mean $\pm \mathrm{SD}$ & $0.119^{\mathrm{a}}$ \\
\hline$\Delta$ Asupan energi & $-160.59 \pm 251.47$ & $81.49 \pm 494.16$ & $0.001^{\mathrm{b}^{*}}$ \\
$\Delta$ Asupan protein & $-8.27 \pm 10.46$ & $11.35 \pm 19.29$ & $0.579^{\mathrm{a}}$ \\
$\Delta$ Asupan lemak & $-4.24 \pm 23.93$ & $2.22 \pm 35.77$ & 0.53 \\
$\Delta$ Asupan karbohidrat & $-21.71 \pm 68.52$ & $0.83 \pm 69.51$ & $0.395^{\mathrm{a}}$ \\
$\Delta$ Asupan serat & $0.05 \pm 5.95$ & $1.50 \pm 5.87$ & $0.662^{\mathrm{b}}$ \\
\hline
\end{tabular}

Keterangan: $p^{*}=$ beda bermakna, $a=$ Independent $t$-test,$b=$ Mann-Whitney 
Tabel 7 menunjukkan tidak terdapat perbedaan yang bermakna pada perubahan asupan energi, lemak, karbohidrat dan serat sebelum dan selama intervensi $(p>0.05)$. Namun terdapat perbedaan yang bermakna pada asupan protein sebelum dan selama intervensi $(p<0.05)$. Kelompok perlakuan mengalami penurunan rerata asupan energi, protein, lemak dan karbohidrat. Kelompok kontrol mengalami peningkatan rerata asupan energi, protein, lemak, karbohidrat dan serat.

\section{Hubungan dan Pengaruh Variabel Perancu terhadap Perubahan GDP pada Kelompok Perlakuan}

Kadar GDP dapat dipengaruhi oleh faktor perancu, sehingga digunakan uji korelasi dan regresi untuk mengetahui variabel perancu mana yang ikut berkontribusi dalam penurunan kadar GDP pada kelompok perlakuan.

Tabel 8. Hubungan dan Pengaruh Variabel Perancu terhadap Perubahan GDP Kelompok Perlakuan

Keterangan: $a=$ uji korelasi pearson, $b=$ uji korelasi spearman's

\begin{tabular}{lccc}
\hline \multicolumn{1}{c}{ Variabel } & $\begin{array}{c}\text { Koefisien } \\
\text { korelasi }\end{array}$ & $\begin{array}{c}\boldsymbol{p} \\
\text { uji korelasi }\end{array}$ & $\begin{array}{c}\boldsymbol{p} \\
\text { uji regresi }\end{array}$ \\
\hline Usia & -0.348 & $0.223^{\mathrm{a}}$ & 0.112 \\
IMT & -0.081 & $0.782^{\mathrm{a}}$ & - \\
$\Delta$ asupan energi & 0.446 & $0.110^{\mathrm{a}}$ & 0.244 \\
$\Delta$ asupan protein & 0.309 & $0.283^{\mathrm{b}}$ & - \\
$\Delta$ asupan lemak & 0.213 & $0.464^{\mathrm{a}}$ & - \\
$\Delta$ asupan karbohidrat & 0.249 & $0.390^{\mathrm{a}}$ & - \\
$\Delta$ asupan serat & 0.361 & $0.205^{\mathrm{b}}$ & 0.079 \\
\hline$=$ uji korelasi pearson, $b=$ uji korelasi spearman's
\end{tabular}

Uji regresi dilakukan apabila hasil uji korelasi $p<0.25$. Hasil uji regresi digunakan untuk mencari variabel dengan korelasi positif yang kuat terhadap perubahan kadar GDP. Berdasarkan tabel di atas tidak ditemukan adanya korelasi positif yang kuat antara beberapa variabel perancu terhadap kadar GDP $(p>0.05)$.

\section{PEMBAHASAN}

Tidak terdapat perbedaan karakteristik rerata usia, IMT dan kadar GDP antara kelompok perlakuan dan kontrol sebelum intervensi yang menunjukkan bahwa subjek penelitian adalah homogen.Seluruh subjek dalam penelitian ini adalah wanita, karena kadar gula darah wanita cenderung lebih tinggi dari pria akibat komposisi lemak tubuh yang lebih tinggi dan aktifitas fisik yang lebih rendah sehingga lebih rentan mengalami kegemukan. ${ }^{14}$ Usia subjek pada penelitian ini paling banyak terdapat pada kategori usia 40-49 tahun (53.57\%) baik pada kelompok perlakuan maupun kontrol. Secara statistik, tidak terdapat perbedaan usia antara kelompok kontrol dan perlakuan $(p>0.05)$. Risiko menderita gangguan toleransi glukosa semakin meningkat seiring bertambahnya usia. Diketahui kadar glukosa darah puasa meningkat $1-2 \mathrm{mg} \%$ per tahun di usia > 30 tahun. Hal ini berkaitan dengan penurunan aktivitas fisik, perubahan komposisi tubuh, perubahan pola makan dan penurunan sensitivitas insulin. ${ }^{15}$
Berdasarkan IMT, subjek pada kelompok perlakuan lebih banyak termasuk dalam kategori obesitas tingkat $1(32.1 \%)$ sedangkan kelompok kontrol paling banyak berada pada kategori IMT overweight (25.0\%). Berdasarkan uji statistik, tidak terdapat perbedaan IMT antara kelompok kontrol dan perlakuan $(p>0.05)$. Resistensi insulin pada penderita obesitas sentral terjadi karena lemak viseral berperan dalam serangkaian perubahan sekresi adipokin yang menghasilkan sejumlah sitokin pro-inflamasi seperti Tumor Necrosis Factors (TNF- $\alpha$ ), Interleukin-1 (IL-1) dan IL-6 yang dapat mengganggu aktifitas normal insulin dalam sel lemak dan sel otot serta toksisitas pada sel- $\beta$ pankreas. Selain itu, terjadi peningkatan kadar asam lemak dalam darah dan peningkatan produksi glukosa hepatik akibat penumpukan lemak dalam hati sehingga meningkatkan risiko terjadinya DM tipe II. ${ }^{16,17}$

Berdasarkan hasil uji statistik tidak ditemukan adanya perbedaan kadar GDP yang signifikan antara kelompok perlakuan dengan kelompok kontrol sebelum intervensi, sehingga dapat dikatakan kadar GDP kedua kelompok adalah homogen. Menurut American Diabetic Association, seseorang termasuk dalam kategori prediabetes apabila memiliki kadar GDP 100-125 mg/dl. ${ }^{9}$ Secara statistik, terdapat perbedaan perubahan kadar GDP antara kelompok perlakuan dan kelompok kontrol. Hal ini menunjukkan ada pengaruh pemberian angkak sebanyak 5.4 gram 
selama 14 hari terhadap penurunan kadar GDP kelompok perlakuan dibandingkan dengan kelompok kontrol yang diberikan seduhan beras sangrai.

Peran angkak dalam menurunkan kadar glukosa darah diketahui berasal dari pigmen angkak yaitu rubropunctamine (merah), rubropunctatin (oranye) dan monascin (kekuningkuningan). Pigmen angkak terutama pigmen merah berpotensi sebagai sumber antioksidan alami karena mengandung zat antosianin dari kelompok flavonoid yang mempunyai antioksidan kuat. Berdasarkan penelitian yang pernah dilakukan sebelumnya, diketahui besar aktivitas antioksidan 0.05 gram angkak yang di ekstrak dalam $10 \mathrm{ml}$ pelarut methanol adalah sebesar $21.24 \% .^{13}$ Penelitian yang dilakukan pada tikus galur wistar hiperglikemik yang diberi angkak sebanyak 150 mg 3 kali sehari selama 3 hari dapat menurunkan kadar glukosa darah dari $146.2 \mathrm{mg} / \mathrm{dl}$ menjadi $118.4 \mathrm{mg} / \mathrm{dl} .{ }^{12}$

Glukosa dapat membentuk glycated hemoglobin dengan hemoglobin akibat reaksi glikosilasi nonenzimatik secara spontan pada kondisi hiperglikemik. Glycated hemoglobin yang teroksidasi akan menghasilkan Reactive Oxygen Spesies (ROS). ROS dapat meningkatkan pembentukan inflammatory factors yaitu TNF- $\alpha$ yang mengakibatkan resistensi insulin pada DM tipe 2 melalui penurunan regulasi reseptor insulin dan substrat reseptor insulin, menghambat aktivitas stimulasi insulin, meningkatkan protein tyrosine phosphatase 1B dan menghambat stimulasi glucose transporter (GLUT-4). Aktivitas antioksidan antosianin yang terkandung dalam angkak dapat meningkatkan toleransi glukosa dengan cara menstabilkan radikal bebas melalui donor gugus hidroksil, memperbaiki stress oksidatif dan mencegah oksidasi glukosa darah. ${ }^{13}$

Penelitian lain menyebutkan angkak dapat memperbaiki sekresi insulin maupun perbaikan kadar glukosa darah dengan cara merangsang pelepasan asetilkolin oleh sistem saraf parasimpatik. Saraf parasimpatik memegang peranan penting dalam regulasi sekresi insuli. Pelepasan asetilkolin dapat meningkatkan keaktifan reseptor muscarinic M3, yang merupakan tipe reseptor dominan yang terdapat di sel $\beta$ pankreas sehingga meningkatkan sekresi insulin oleh sel $\beta$ pankreas. ${ }^{18}$

Faktor lain yang dimungkinkan dapat berpengaruh terhadap kadar GDP dan menjadi variabel perancu penurunan kadar GDP adalah asupan protein. Berdasarkan data food recall, terdapat penurunan asupan protein pada kelompok perlakuan sebesar 8.27 gram dan peningkatan asupan protein pada kelompok kontrol sebesar 11.35 gram. Uji independent t-test menunjukkan terdapat perbedaan perubahan asupan protein yang bermakna antara kelompok perlakuan dan kelompok kontrol $(p=0.001)$. Penurunan asupan protein pada kelompok perlakuan dimungkinkan terjadi karena adanya perubahan pola makan, seperti menghilangkan waktu makan utama dan mengurangi porsi makan. Penurunan asupan protein ini mengakibatkan kalori yang masuk dalam tubuh ikut menurun sehingga dapat membantu mengendalikan kadar glukosa darah. Konsumsi makanan rendah kalori dapat membantu mengendalikan kadar glukosa darah. Angkak juga mengandung serat larut air yang dianjurkan untuk dikonsumsi oleh penderita diabetes karena dapat meningkatkan viscositas lambung sehingga penyerapan glukosa diperlambat. ${ }^{19}$

Meskipun asupan energi, protein, lemak dan karbohidrat pada kelompok perlakuan mengalami penurunan serta adanya perubahan pola makan, namun secara statistik tidak terdapat korelasi positif yang kuat antara perubahan asupan makan dengan penurunan kadar GDP subjek kelompok perlakuan. Hal ini terlihat dari uji regresi linier yang menyatakan tidak ada variabel perancu yang mempunyai korelasi positif yang kuat dengan kadar GDP $(p>0.05)$.

Pemberian angkak sebanyak 5.4 gram selama 14 hari secara signifikan dapat menurunkan kadar glukosa darah puasa subjek prediabetes. Adanya perbedaan perubahan asupan protein yang bermakna antara kelompok perlakuan dan kelompok kontrol bukan merupakan variabel perancu dalam penurunan kadar GDP pada kelompok perlakuan dibuktikan dari hasil uji statistik regresi linier.

\section{KETERBATASAN PENELITIAN}

Tidak dilakukan uji laboratorium untuk mengetahui besar kandungan antosianin angkak.

\section{SIMPULAN}

Terdapat penurunan kadar glukosa darah puasa yang bermakna sebesar $9.14 \mathrm{mg} / \mathrm{dl}$ setelah pemberian angkak sebanyak 5.4 gram selama 14 hari.

\section{SARAN}

Penderita prediabetes dianjurkan untuk mengkonsumsi angkak sebanyak 5.4 gram selama 
14 hari karena dapat membantu mengontrol kestabilan kadar glukosa darah.

\section{UCAPAN TERIMA KASIH}

Puji syukur penulis panjatkan ke hadirat Allah SWT atas limpahan rahmat-Nya kepada penulis. Ucapan terima kasih penulis ucapkan kepada karyawati kantor BPS, BPPT, Bappeda dan yayasan Pangudi luhur Kota Semarang atas kesedian menjadi subjek penelitian dan membantu kelancaran penelitian ini; reviewer, dr. Apoina Kartini, M.Kes dan Ninik Rustanti, STP,M.Si atas segala saran dan kritik dalam perbaikan artikel ini; orangtua dan teman-teman atas doa dan semangatnya serta semua pihak yang telah mendukung penyusunan karya tulis ilmiah ini.

\section{DAFTAR PUSTAKA}

1. Rolfes SR, Pinna K, Whitney E. Diabetes mellitus. Dalam: Understanding normal and clinical nutrition. $8^{\text {th }}$ edition. Canada: Wadsworth; 2009. p.811-33

2. Schteingart DE. Pankreas: Metabolisme glukosa dan diabetes melitus. Dalam: Price AS, Wilson LM. Patofisiologi, konsep klinis proses-proses penyakit. Jakarta: EGC; 2006. p.1259-72

3. World Health Organization. Global health risks: Mortality and burden of disease attributable to selected major risks 2009. [cited 2013 April $25^{\text {th }}$. Available from URL: http://www.who.int/healthinfo/global_burden_dise ase/GlobalHealthRisks report full.pdf

4. Sicree R, Shaw J, Zimmet P. The global burden: diabetes and impaired glucose tolerance. International Diabetes Foundation $4^{\text {th }}$ edition. [cited 2013 April $12^{\text {th }}$ ]. Available from URL: http://www.idf.org/sites/default/files/The_Global_ Burden.pdf

5. Wild S, Roglic G, Green A, Sicree R, King H. Global prevalence of diabetes: Estimates for the year 2000 and Projections for 2030. Diabetes Care 2004; 27:1047-53

6. World Health Organization. World health statistics 2012. [cited 2013 April $3^{\text {rd }}$ ] Available from URL: http://www.who.int/gho/publications/world_health statistics/EN_WHS2012_Full.pdf

7. Dinas Kesehatan Kota Semarang. Profil kesehatan Kota Semarang 2010. Semarang : Dinas Kesehatan Kota Semarang, 2010.

8. Sizer FS, Whitney E. The Carbohydrates : Sugar, Strach, Glycogen and fibre. Dalam: Nutrition Concept and Controversies $11^{\text {th }}$ edition. Canada: Wadsworth; 2008. p.121-38.

9. American Diabetic Association. Standards of medical care in diabetes. 2012. [cited 2013 March $\left.7^{\text {th }}\right]$. Available from URL:
http://care.diabetesjournals.org/content/35/Supple ment 1/S11.full.pdf+html

10. Soewondo P, Pramono LA. Prevalence, characteristics, and predictors of prediabetes in Indonesia. Med J Indonesia. 2011;20(4): 283-94

11. A Rajasekaran, M Kalaivani, R Sabitha. Anti diabetic activity of aqueous extract of Monascus purpureus fermented rice in high cholesterol diet fed-streptozotocin-induced diabetic rats. Asian J of Scientific Research. 2009; 4: 180-9.

12. Su CF, Liu IM, Cheng JT. Improvement of insulin resistance by Hon-Chi in fructose-rich chow-fed rats. Food Chemistry. 2007; 45-52

13. Wanti S. Pengaruh berbagai jenis beras terhadap aktivitas antioksidan pada angkak oleh Monascus purpureous. Universitas Sebelas Maret; 2008.

14. Soegondo S, Soewondo P, Subekti I. Penatalaksanaan diabetes melitus terpadu. Jakarta : Pusat Diabetes dan Lipid RSUP Nasional Dr. Cipto Mangunkusumo Fakultas Kedokteran Universitas Indonesia; 2002

15. Rochmah W. Diabetes Melitus pada Usia Lanjut. Dalam: Sudoyo AW, Setiyohadi B, Alwi I, Simadibrata M, Setiati S, editors. Buku Ajar Ilmu Penyakit Dalam. Edisi 4. Jakarta: Pusat Penerbitan IPD FKUI; 2007.p.1915-18

16. Mlinar B, Marc J, Janez A, Pfeifer M. Molecular mechanisms of insulin resistance and associated diseases. 375 (2007); 20-35

17. Haffner SM. Abdominal obesity, insulin resistance and cardiovascular risk in pre-diabetes and type 2 diabetes. Eur Heart J Supplements. 2006; B20-25

18. Chen CC, Liu IM. Release of acetylcholine by Hon-Chi to raise insulin secretion in Wistar rats. Neuroscience letter. 2006; 117-21

19. Perkumpulan Endokrinologi Indonesia. Konsensus pengelolaan dan pencegahan diabetes melitus tipe 2 di Indonesia. Jakarta : PB. PERKENI; 2006.p.314, 30-31 